Article

\title{
Optimization of an Autochthonous Bacterial Consortium Obtained from Beach Sediments for Bioremediation of Petroleum Hydrocarbons
}

\author{
Rafaela Perdigão ${ }^{1,2}{ }^{(\mathbb{D}}$, C. Marisa R. Almeida ${ }^{1, * \mathbb{C}}$, Filipa Santos ${ }^{1}$, Maria F. Carvalho ${ }^{1} \mathbb{D}^{-}$and Ana P. Mucha ${ }^{1,3}$ \\ 1 Interdisciplinary Centre of Marine and Environmental Research of the University of Porto, Novo Edifício do \\ Terminal de Cruzeiros do Porto de Leixões, Avenida General Norton de Matos, S/N, 4450-208 Matosinhos, \\ Portugal; rafaela_mat94@hotmail.com (R.P.); pipa.santos2@gmail.com (F.S.); mcarvalho@ciimar.up.pt (M.F.C.); \\ amucha@ciimar.up.pt (A.P.M.) \\ 2 Institute of Biomedical Sciences Abel Salazar, University of Porto, Rua de Jorge Viterbo Ferreira, 228, \\ 4050-313 Porto, Portugal \\ 3 Faculty of Sciences, University of Porto, Rua do Campo Alegre 790, 4150-171 Porto, Portugal \\ * Correspondence: calmeida@ciimar.up.pt; Tel.: +351-223-401-822
}

check for

updates

Citation: Perdigão, R.; Almeida, C.M.R.; Santos, F.; Carvalho, M.F.; Mucha, A.P. Optimization of an Autochthonous Bacterial Consortium Obtained from Beach Sediments for Bioremediation of Petroleum Hydrocarbons. Water 2021, 13, 66. https://doi.org/10.3390/w13010066

Received: 13 November 2020 Accepted: 26 December 2020 Published: 31 December 2020

Publisher's Note: MDPI stays neutral with regard to jurisdictional clai$\mathrm{ms}$ in published maps and institutional affiliations.

Copyright: (C) 2020 by the authors. Licensee MDPI, Basel, Switzerland. This article is an open access article distributed under the terms and conditions of the Creative Commons Attribution (CC BY) license (https:// creativecommons.org/licenses/by/ $4.0 /)$.

\begin{abstract}
Oil spill pollution remains a serious concern in marine environments and the development of effective oil bioremediation techniques are vital. This work is aimed at developing an autochthonous hydrocarbon-degrading consortium with bacterial strains with high potential for hydrocarbons degradation, optimizing first the growth conditions for the consortium, and then testing its hydrocarbon-degrading performance in microcosm bioremediation experiments. Bacterial strains, previously isolated from a sediment and cryopreserved in a georeferenced microbial bank, belonged to the genera Pseudomonas, Rhodococcus and Acinetobacter. Microcosms were assembled with natural seawater and petroleum, for testing: natural attenuation (NA); biostimulation (BS) (nutrients addition); bioaugmentation with inoculum pre-grown in petroleum (BA/P) and bioaugmentation with inoculum pre-grown in acetate (BA/A). After 15 days, a clear blending of petroleum with seawater was observed in BS, BA/P and BA/A but not in NA. Acetate was the best substrate for consortium growth. BA/A showed the highest hydrocarbons degradation (66\%). All bacterial strains added as inoculum were recovered at the end of the experiment. This study provides an insight into the capacity of autochthonous communities to degrade hydrocarbons and on the use of alternative carbon sources for bacterial biomass growth for the development of bioremediation products to respond to oil spills.
\end{abstract}

Keywords: autochthonous bacteria; oil spills; bioaugmentation; biostimulation; petroleum; bioremediation; beach sediments

\section{Introduction}

Today, society still depends on fossil fuels for energy production, commerce, and industry, demanding a continuous exploitation and transport of petroleum and its derivatives by sea. Therefore, marine environments are at constant risk of oil spills [1], especially in coastal areas, where maritime transportation often share routes [2]. Oil spills have a high impact in these ecosystems [3] and frequently lead to large mortalities of the associated fauna and flora [4]. The Deepwater Horizon (2010), the Prestige (2002) and the Exxon Valdez (1989) oil spills are some examples that have marked history for their high negative impact on the environment and marine wildlife.

The main problematic inherent to the spillage of crude oil or petroleum is its complex composition, a mixture of alkanes, aromatic hydrocarbons, resins and asphaltenes [5], in which some components can be recalcitrant and extremely toxic to marine organisms [6,7]. Once the oil reaches the sea, it undergoes several weathering processes, like evaporation, 
dissolution, dispersion, sedimentation, photo-oxidation and biodegradation [8-10]), depending on the climatic conditions, hydrodynamics and location of the spillage $[3,11]$. These processes keep on going also when the spill reaches the shore and exposed beaches.

Some marine microorganisms, such as fungi, yeasts and bacteria, are capable of degrading petroleum hydrocarbons. Aspergillus spp. and Gordonia spp. are examples of fungi and yeast hydrocarbon-degraders [4,12]. However, in marine environments, bacteria are thought to be the key petroleum-degrading organisms [6] with a variety of degradation pathways [13]. They use the carbon from the petroleum as a source of energy, breaking its compounds into others with lower molecular weight [14]. Some examples of bacterial species commonly linked to the degradation of petroleum hydrocarbons are Rhodococcus erythropolis [15,16], Acinetobacter spp. [17], Alcanivorax borkumensis [18] and Bacillus spp. [19].

Most of the times, natural microbial communities cannot respond fast enough to prevent negative outcomes of the spills, thus remediation technologies must be applied to clean-up such environments. Current oil spill clean-up technologies focus on mechanical removal and on the use of chemical dispersants, which can cause additional contamination to the environment and marine organisms $[3,20]$. In addition, these techniques may not completely remove the oil spilled and do not assure the ecological restoration of the impacted environment [21].

Bioremediation is based on the natural ability of some microorganisms, such as bacteria, to degrade pollutants and has proven to be an ecological and effective remediation technique, which could be applied as an alternative or in combination with already existing traditional oil spill remediation techniques. The addition of nutrients and/or biosurfactants (biostimulation) or of efficient oil degrading microorganisms (bioaugmentation) can enhance the degradation of hydrocarbon compounds [22-26]. For bioaugmentation, an input in the bioremediation process of exogenous or of autochthonous oil-degrading bacteria can be considered. In fact, there are already several patents of competent exogenous oil-degrading microorganisms, which include strains from the genus Pseudomonas, Acinetobacter, Rhodococcus and Bacillus [27].

However, the use of autochthonous microorganisms can be more advantageous, because they are better adapted to the affected environment, leading to a better efficiency in oil degradation [28]. This strategy can be more successful than the input of exogenous microorganisms, which commonly cannot compete with the natural microbial community, and therefore, might not prosper or enhance the hydrocarbons' degradation [29,30]. In addition, the use of autochthonous microorganisms avoids the unpredictable ecological impacts that the introduction of non-native organisms into a particular environment can cause. The importance and success of autochthonous bioaugmentation has been increasingly approached in recent studies and its possible application in the field is being regarded as an efficient strategy $[28,31,32]$. When applying bioaugmentation treatments, the use of a consortium of bacterial strains, rather than a single strain, can be more effective in the degradation of the petroleum hydrocarbons, as different strains can degrade different petroleum compounds, thus leading to a broader spectrum of action [33,34].

After an oil spill, contamination may reach coastal areas, namely several beaches, impacting their sediments. Coastal areas are ecologically very important; they provide a great diversity of species and they offer numerous benefits to humans. Protecting coastal environments is therefore crucial and the development of strategies to clean these contaminated ecosystems to facilitate their recovery is urgent. Previous studies have indicated that autochthonous microorganisms from coastal sediments have high potential for degradation of hydrocarbons [24,35-37]. In a patent search on microbial bioremediation techniques of seawater contaminated with petroleum hydrocarbons done by Villela et al. [27], most of the patents were based on bioaugmentation treatments with individual strains or consortia of exogenous microorganisms. Based on this search, the authors claimed that there is a worldwide need for innovative activities for bioremediation of petroleum contaminated seawater. In the work of Villela et al. [27], patents of autochthonous or native microorganisms were 
never mentioned. However, after a search on Google Patents and European patent office, only one patent (US8.444.962B2) referred the usage of an autochthonous bacterial consortia to bioremediate petroleum hydrocarbons in seawater [38]. These investigations indicate that the research on autochthonous bioremediation technologies is still scarce but very relevant for future implementation of these nature- based solutions. According to a recent study of Aldieri et al. [39] the implementation of environmental knowledge spillovers on companies in the fields of energy, water, and land resources, can positively affect company productivity. This would facilitate the economic transition to more sustainable and less polluting technologies. Considering the needs for more efficient and innovative bioremediation techniques to tackle oil spill pollution in marine environments, the main goals of this work were to: (1) develop an autochthonous petroleum-degrading consortium with bacterial strains showing high potential for hydrocarbons degradation, (2) optimize the growth conditions of that consortium using different carbon sources, and (3) evaluate the efficiency of the developed consortium to degrade petroleum hydrocarbons in a microcosm experiment, using different bioremediation treatments.

\section{Materials and Methods}

\subsection{Sampling Site and Assembling of an Autochthonous Hydrocarbons-Degrading Bacterial Consortium}

Five bacterial strains (named CPN1, CPN2, CPN3, CPN4 and CPN5), isolated from

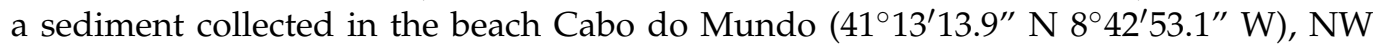
Portugal [40], were used in the current study due to their high potential to degrade petroleum hydrocarbons. This sampling site is located near an oil refinery (Petrogal, Matosinhos, Portugal) and is located about $4 \mathrm{~km}$ from the Leixões Harbor. The bacterial strains were isolated after exposure of the beach sediment to petroleum (Arabian light crude-oil, provided by an oil refinery), in Bushnell-Haas broth (Difco) supplemented with $2 \% \mathrm{NaCl}(v / v)$ and nutrients $\left(40 \mathrm{mM} \mathrm{N}\left(\mathrm{KNO}_{3}\right)\right.$ and $\left.8 \mathrm{mM} \mathrm{P}\left(\mathrm{KH}_{2} \mathrm{PO}_{4}\right)\right)$, for 15 days, in a sediment/medium/petroleum proportion of 10:20:0.5 $(v / v / v)$. After the enrichment phase, bacteria present in the microbial culture were cultured in plate count agar (PCA) (Liofilchem, Roseto degli Abruzzi, Italy). The PCA medium had no hydrocarbon in its composition, and some oil-degrading bacteria might not be isolated, but, being that the PCA was a medium rich in nutrients and carbon, that promotes the growth of several bacterial groups, it was assumed that it would be appropriate. From this procedure, five bacterial strains were isolated and cryopreserved at $-80^{\circ} \mathrm{C}$, individually, in a georeferenced microbial bank.

The cryopreserved bacterial strains were then unfrozen and a sample of each was taken, ten-fold diluted in a sterile saline solution $(0.85 \%)$, spread out onto PCA plates, and cultivated at $28^{\circ} \mathrm{C}$. After $3-4$ days of incubation at $28^{\circ} \mathrm{C}$, biomass from each of the 5 strains (equal amount of each strain) was collected and added to $1 \mathrm{~mL}$ of sterilized Bushnell-Haas broth (Difco) supplemented with $2 \% \mathrm{NaCl}(v / v)$. The amount of biomass was selected in order to have an optical density (OD, measured at $600 \mathrm{~nm}$ ) of ca. 0.1. The assembled consortium was used as inoculum for the experiments. Another portion of biomass of each bacterial strain was also collected for DNA extraction for phylogenetic identification.

\subsection{Growth Optimization of the Bacterial Consortium with Different Carbon Sources}

With this experiment we aimed to produce an efficient petroleum-degrading bacterial consortium to be used as an inoculum in the autochthonous bioaugmentation, without using petroleum or other hazardous compounds as carbon sources. For that we tested the use of acetate as single carbon source, and compared it with petroleum (the same crude oil used for the isolation of the bacterial strains, containing aliphatic and aromatic hydrocarbons and other compounds as resins and asphaltenes), a mixture of four polycyclic aromatic hydrocarbons (PAHs) (representing a less degradable fraction of the crude oil), and a combination of PAHs with acetate (to test the effect of acetate without losing the selective pressure associated with the presence of hydrocarbons). This assay was set up in 
$100 \mathrm{~mL}$ glass flasks containing $10 \mathrm{~mL}$ of sterile Bushnell-Haas medium supplemented with $2 \% \mathrm{NaCl}$ and inoculated with an equal mixture of the five strains (as described above) to obtain an initial $\mathrm{OD}_{600}$ of 0.1 . The four different carbon sources were individually added to the flasks: petroleum (P); sodium acetate (A); a mixture of four PAHs-naphthalene, anthracene, fluoranthene and pyrene (all from Acros Organics); and a mixture of sodium acetate and the four PAHs (A + PAHs), at a final carbon concentration of, respectively, 1 , $0.1,0.1$ and $0.1 \%(v / v)$. Each treatment was tested in triplicate.

The solution of PAHs was made by weighting $0.1 \mathrm{~g}$ of each PAH, dissolving them in $10 \mathrm{~mL}$ of dichloromethane (final concentration of each PAH in the solution of $10 \mathrm{~g} \mathrm{~L}^{-1}$ ) and adding directly to the flasks. The solution of sodium acetate was made by dissolving $2 \mathrm{~g}$ in $20 \mathrm{~mL}$ of deionized water (final concentration of $10 \%$ ). One hundred microliters of both solutions were used to feed each flask in the above-described experiment. In the flasks fed with petroleum, $100 \mu \mathrm{L}$ of petroleum, filtered through $0.2 \mu \mathrm{m}$ sterile cellulose acetate membrane filters (VWR), were added to each flask.

The flasks were kept closed, but opened daily for aeration of the flasks, under constant agitation (100 rpm), at $28^{\circ} \mathrm{C}$ for 15 days. After this period, samples were collected to evaluate the abundance of hydrocarbon-degrading bacteria through the most probable number (MPN) method.

\subsection{Microcosm Bioremediation Experiment}

For the bioremediation experiment, two inocula were prepared, one with petroleum and another with sodium acetate that was the best performing carbon source based on the growth optimization experiment (Results Section 3.2). For inoculum preparation, a mixture of the five bacterial strains was inoculated in $250 \mathrm{~mL}$ sterilized glass flasks containing $20 \mathrm{~mL} \mathrm{BH}$ medium supplemented with $2 \% \mathrm{NaCl}$, with an $\mathrm{OD}_{600 \mathrm{~nm}}$ of 1 . Half of the flasks were supplemented with petroleum $(\mathrm{P})$ as the carbon source, in a 20:0.5 $(v / v)$ ratio. The other half was supplemented with sodium acetate (A) that was added daily to the cultures at a final concentration of $1 \mathrm{~g} \mathrm{~L}^{-1}$. This feeding strategy was based on a previous optimization test where daily supplementation was compared with supplementation twice a week (Supplementary Material Figure S1). For each carbon source, triplicate flasks were prepared and incubated closed for 4 days, at $28{ }^{\circ} \mathrm{C}$, under constant agitation (100 rpm). After this period, the cultures were centrifuged and the resulting pellet was re-suspended in $1 \mathrm{~mL}$ of unsterile natural seawater, the same to be used in the microcosm experiment, to create inocula pre-grown in acetate $(\mathrm{A})$ or in petroleum $(\mathrm{P})$.

For the bioremediation experiment, microcosms were assembled in $100 \mathrm{~mL}$ sterilized glass flasks containing $20 \mathrm{~mL}$ of natural seawater collected from a beach in Matosinhos, NW Portugal, and filter sterilized petroleum $(\mathrm{P})$ in the ratio of 20:0.5 $(v / v)$. We used natural seawater, instead of a sterilized medium, as we want to simulate, on a small scale, a spill of oil in the natural environment, and compare the bioremediation treatments (biostimulation and bioaugmentation) with the natural attenuation performed by the natural communities. Four different conditions were tested: (i) natural attenuation (NA) (seawater + petroleum); (ii) biostimulation (BS) (seawater + petroleum + nutrients); (iii) bioaugmentation with inoculum pre-grown in petroleum $(\mathrm{BA} / \mathrm{P})($ seawater + petroleum + nutrients + inoculum $\mathrm{P})$ and (iv) bioaugmentation with inoculum pre-grown in acetate (BA/A) (seawater + petroleum + nutrients + inoculum A) (Supplementary Material Figure S2). In the BS, BA/P and BA/A treatments, nutrients were added in the form of $\mathrm{KNO}_{3}(40 \mathrm{mM} \mathrm{N})$ and $\mathrm{KH}_{2} \mathrm{PO}_{4}$ $(8 \mathrm{mM} \mathrm{P})$, with a final ratio of $\mathrm{C} / \mathrm{N} / \mathrm{P}$ of $(100: 10: 1)$ as described in Almeida et al. [24], for optimal bioremediation rates.

Each condition was set up in triplicate, except for the NA treatment, where 6 flasks were prepared, with 3 removed at the beginning of the assay and used as initial samples (T0) for MPN and total petroleum hydrocarbons (TPHs) analyses. For all treatments, culture samples were collected at the beginning of the experiment for evaluation of abundance of hydrocarbon-degrading bacteria through the MPN method $(0.2 \mathrm{~mL})$. 
The experiment was carried out for 15 days with orbital agitation (100 rpm), in the dark, at room temperature. To improve blending and aeration, the flasks were kept open and manually shaken once every day. At the end of the experiment, culture samples were collected for evaluation of abundance of hydrocarbon-degrading bacteria through the MPN method as described in the next section $(0.2 \mathrm{~mL})$, and for bacterial isolation and further phylogenetic identification $(1 \mathrm{~mL})$. The remaining cultures were kept in the flasks and frozen at $-20^{\circ} \mathrm{C}$ for hydrocarbons levels (see below) assessment.

\subsection{Abundance of Hydrocarbon-Degrading Bacteria}

The abundance of hydrocarbon-degrading bacteria was evaluated by the MPN method adapted from Wrenn and Venosa [41], as described in Almeida et al. [24].

For that, in 96-well plates, tenfold dilutions of the initial sample $(20 \mu \mathrm{L})$ were inoculated in $180 \mu \mathrm{L}$ of Bushnell-Haas medium supplemented with $2 \% \mathrm{NaCl}$ and $10 \mu \mathrm{L}$ of filter sterilized petroleum as the only carbon source. After a 15 day-incubation period at room temperature, filter sterilized iodonitrotetrazolium violet (INT; $3 \mathrm{~g} \mathrm{~L}^{-1}$ ) was added to each well and positive wells (colored in violet) were counted after an overnight incubation.

\subsection{Total Petroleum Hydrocarbons (TPHs) Analysis}

For TPHs determination, flasks containing the cultures from the microcosm bioremediation experiment were defrosted. After homogenization, the cultures were transferred to glass vials and hydrocarbons were extracted by adding tetrachloroethylene and incubating in an ultrasonic bath for $15 \mathrm{~min}$, as described in Almeida et al. [24]. To ensure the full collection of petroleum, including the petroleum attached to the vial walls, tetrachloroethylene was also added to the previous vials, once empty, and an ultrasonic extraction was also carried out. The extracted TPHs were analyzed by Fourier transform infrared spectrophotometry (Jasco FT/IR-460 Plus) as described in Almeida et al. [24]. The concentration of TPHs obtained for each treatment was the sum of the concentration of TPHs in both extracts (microbial culture and empty vial).

\subsection{Isolation of the Potential Hydrocarbon-Degrading Bacteria}

For each treatment tested in the microcosms bioremediation experiment, a combined sample of the respective triplicates was taken, ten-fold diluted in sterile saline solution $(0.85 \%)$ and spread out onto PCA plates. After 3-4 days of incubation at $28^{\circ} \mathrm{C}$, morphologically different colonies were described and purified. Isolated strains were then preserved in $21 \%$ glycerol at $-80^{\circ} \mathrm{C}$ and biomass of each strain was also collected for DNA extraction. PCA was selected as explained above for bacterial strains isolation and growth.

\subsection{Identification of Bacterial Strains}

For phylogenetic identification of strains CPN1-CPN5 and of strains isolated at the end of the bioremediation experiment, DNA was extracted by using the E.Z.N.A. ${ }^{\circledR}$ Bacterial DNA Kit (Omega Bio-Tek, Norcross, GA, USA) and quantified with the kit Quant-it HsDNA in the Qubit fluorometer (Invitrogen). For phylogenetic identification, the V1-V9 regions of the bacterial 16S rRNA gene were amplified with the universal primers 27F (5' AGAGTTTGATCMTGGCTCAG $3^{\prime}$ ) and 1492R (5' TACGGYTACCTTGTTACGACTT $\left.3^{\prime}\right)$. The PCR mixture, with a final volume of $10 \mu \mathrm{L}$, contained: $5 \mu \mathrm{L}$ of Qiagen Multiplex PCR Master Mix (Qiagen, Hilden, Alemanha), $1 \mu \mathrm{L}$ of each primer $(2 \mathrm{mM})$ and $3 \mu \mathrm{L}$ of DNA sample. PCR conditions were as follows: initial cycle at $95^{\circ} \mathrm{C}$ for $15 \mathrm{~min}, 30$ cycles at $94{ }^{\circ} \mathrm{C}$ for $30 \mathrm{~s}, 48{ }^{\circ} \mathrm{C}$ for $90 \mathrm{~s}, 72{ }^{\circ} \mathrm{C}$ for $2 \mathrm{~min}$ and a final cycle at $72{ }^{\circ} \mathrm{C}$ for $10 \mathrm{~min}$. Amplified samples were run in a 1.5\% agarose gel containing SYBR Safe (Thermo Fisher Scientific, Waltham, MA, USA) and the resulting PCR products were sequenced at Genomics i3S Scientific Platform (Porto, Portugal). The resulting 16S rDNA sequences were aligned using the Geneious software (version 11.1.4), and the consensus sequences were compared to those present in the nucleotide collection database of the National Center for Biotechnology Information (NCBI) and to two additional databases, to confirm the 
results, EZTaxon database (http:/ / www.ezbiocloud.net) and Ribosomal Database Project (https://rdp.cme.msu.edu/index.jsp). The 16S rRNA gene sequences of the identified strains were deposited in GenBank (NCBI, Bethesda, MD, USA) under the accession numbers indicated in Tables 1 and 2.

Table 1. Phylogenetic identification of the bacterial strains (CPN1, CPN2, CPN3, CPN4 and CPN5) used to prepare the inocula for the microcosm bioremediation experiment.

\begin{tabular}{cccccc}
\hline Isolates & Closest Identification & Sequence Length & \% Similarity * & Phylum & Accession Number \\
\hline CPN1 & Pseudomonas sp. & 1401 & 99.14 & Proteobacteria & MN833701 \\
CPN2 & Rhodococcus erythropolis & 1362 & 99.93 & Actinobacteria & MN833712 \\
CPN3 & Rhodococcus erythropolis & 1369 & 100 & Actinobacteria & MN833713 \\
CPN4 & Pseudomonas sp. & 1390 & 99.28 & Proteobacteria & MN833702 \\
CPN5 & Acinetobacter johnsonii & 1399 & 99.64 & Proteobacteria & MN833683 \\
\hline
\end{tabular}

* Similarity percentages according to the nucleotide collection database of the NCBI.

Table 2. Phylogenetic identification of bacterial strains isolated at the end of the microcosms bioremediation experiment for the different treatments: natural attenuation (NA), biostimulation (BS), bioaugmentation with inoculum pre-grown in petroleum $(\mathrm{BA} / \mathrm{P})$ and bioaugmentation with inoculum pre-grown in acetate (BA/A). In bold isolate similar to the bacterial strains (CPN1-CPN5) used as inocula for the bioaugmentation treatments.

\begin{tabular}{|c|c|c|c|c|c|}
\hline Isolates & Closest Identification & Sequence Length & $\%$ Similarity * & Phylum & Accession Number \\
\hline NA1 & Rhodobacteraceae ** & 1345 & 100 & Proteobacteria & MN833708 \\
\hline NA2 & Pseudomonas sp. & 1399 & 99.79 & Proteobacteria & MN833692 \\
\hline NA3 & Pseudomonas sabulinigri & 1399 & 99.5 & Proteobacteria & MN833688 \\
\hline NA4 & Pseudomonas sp. & 1393 & 99.35 & Proteobacteria & MN833693 \\
\hline NA5 & Microbacterium oxydans & 1382 & 100 & Actinobacteria & MN833684 \\
\hline NA6 & Pseudomonas sp. & 1395 & 100 & Proteobacteria & MN833694 \\
\hline NA7 & Pseudomonas aestusnigri & 1391 & 99.71 & Proteobacteria & MN833685 \\
\hline NA9 & Pseudomonas stutzeri & 1387 & 99.86 & Proteobacteria & MN833696 \\
\hline NA10 & Pseudomonas alcaligenes *** & 1385 & 98.27 & Proteobacteria & MN833691 \\
\hline BS1 & Pseudomonas taeanensis & 1337 & 99.93 & Proteobacteria & MN833697 \\
\hline BS2 & Rhodobacteraceae $* *$ & 1331 & 99.85 & Proteobacteria & MN833706 \\
\hline BS4 & Pseudomonas taeanensis & 1397 & 99.86 & Proteobacteria & MN833699 \\
\hline BS5 & Rhodobacteraceae ** & 1350 & 100 & Proteobacteria & MN833707 \\
\hline BS7 & Pseudomonas pachastrellae & 1408 & 100 & Proteobacteria & MN833687 \\
\hline BS8 & Pseudomonas sp. & 1390 & 99.21 & Proteobacteria & MN833690 \\
\hline BS9 & Pseudomonas taeanensis & 1407 & 99.79 & Proteobacteria & MN833700 \\
\hline BS11 & Rhodococcus erythropolis & 1392 & 99.86 & Actinobacteria & MN833711 \\
\hline BS13 & Pseudomonas taeanensis & 1386 & 99.78 & Proteobacteria & MN833698 \\
\hline BS14 & Pseudomonas stutzeri & 1403 & 99.93 & Proteobacteria & MN833695 \\
\hline BAP1 & Rhodobacteraceae ** & 1332 & 100 & Proteobacteria & MN833705 \\
\hline BAP2 ${ }^{a}$ & Rhodococcus erythropolis & 1363 & 99.93 & Actinobacteria & MN833710 \\
\hline BAP3 $^{a}$ & Pseudomonas sp. & 1384 & 99.21 & Proteobacteria & MN833686 \\
\hline BAP4 & Pusillimonas sp. & 1405 & 99.15 & Proteobacteria & MN833704 \\
\hline BAP5 ${ }^{a}$ & Acinetobacter johnsonii & 1400 & 99.22 & Proteobacteria & MN833682 \\
\hline BAA1 & Salinibacterium amurskyense & 1364 & 99.78 & Actinobacteria & MN833714 \\
\hline BAA2 ${ }^{\text {a }}$ & Rhodococcus erythropolis & 1366 & 100 & Actinobacteria & MN833709 \\
\hline BAA3 $^{\text {a }}$ & Pseudomonas sp. & 1396 & 99.35 & Proteobacteria & MN833689 \\
\hline BAA4 ${ }^{\text {a }}$ & Acinetobacter johnsonii & 1408 & 99.93 & Proteobacteria & MN833681 \\
\hline BAA5 & Pusillimonas sp. & 1390 & 99.21 & Proteobacteria & MN833703 \\
\hline
\end{tabular}

* similarity percentages according to the nucleotide collection database of the NCBI; ** the identification of the isolates was made only until the family level; ${ }^{* *}$ the isolate may represent a new species, with $98 \%$ of similarity. ${ }^{\text {a }}$ isolate similar to the bacterial strains (CPN1-CPN5) used as inocula for the bioaugmentation treatments.

\subsection{Statistical Analyses}

Triplicates of MPN and TPHs concentrations were analyzed and their mean values $(n=3)$ and standard deviations were determined. For both parameters, statistical analysis was made with the STATISTICA program (version 13.2), where a parametric Student's $t$-test, 
with the mean values and their standard deviations, was applied. Significant differences were considered when $p$ values were equal or below $0.05 \mathrm{MPN} / \mathrm{mL}$; values were Log 10 transformed.

\section{Results}

\subsection{Autochthonous Hydrocarbons-Degrading Bacterial Consortium}

The hydrocarbon degrading potential of the 5 bacterial strains (CPN1, CPN2, CPN3, CPN4 and CPN5) isolated from the beach sediment after an enrichment with crude oil was tested individually and as a consortium (MIX). Results from MPN showed that all the individual strains and the mixture of the five strains (MIX), displayed an ability to degrade petroleum hydrocarbons (Figure 1). The inocula prepared with the bacterial strains CPN2 to CPN5 presented densities of hydrocarbon degraders between $10^{6}$ and $10^{9} \mathrm{MPN} / \mathrm{mL}$, significantly $(p \leq 0.05)$ lower than the inocula prepared with CPN1 and the mixture of the five strains (MIX), which showed densities $>10^{11} \mathrm{MPN} / \mathrm{mL}$. In spite of no significant differences observed between CPN1 and MIX, the latter one was selected for further studies as we assumed that a consortium of 5 bacterial strains presents higher potential for bioremediation experiments than a single strain.

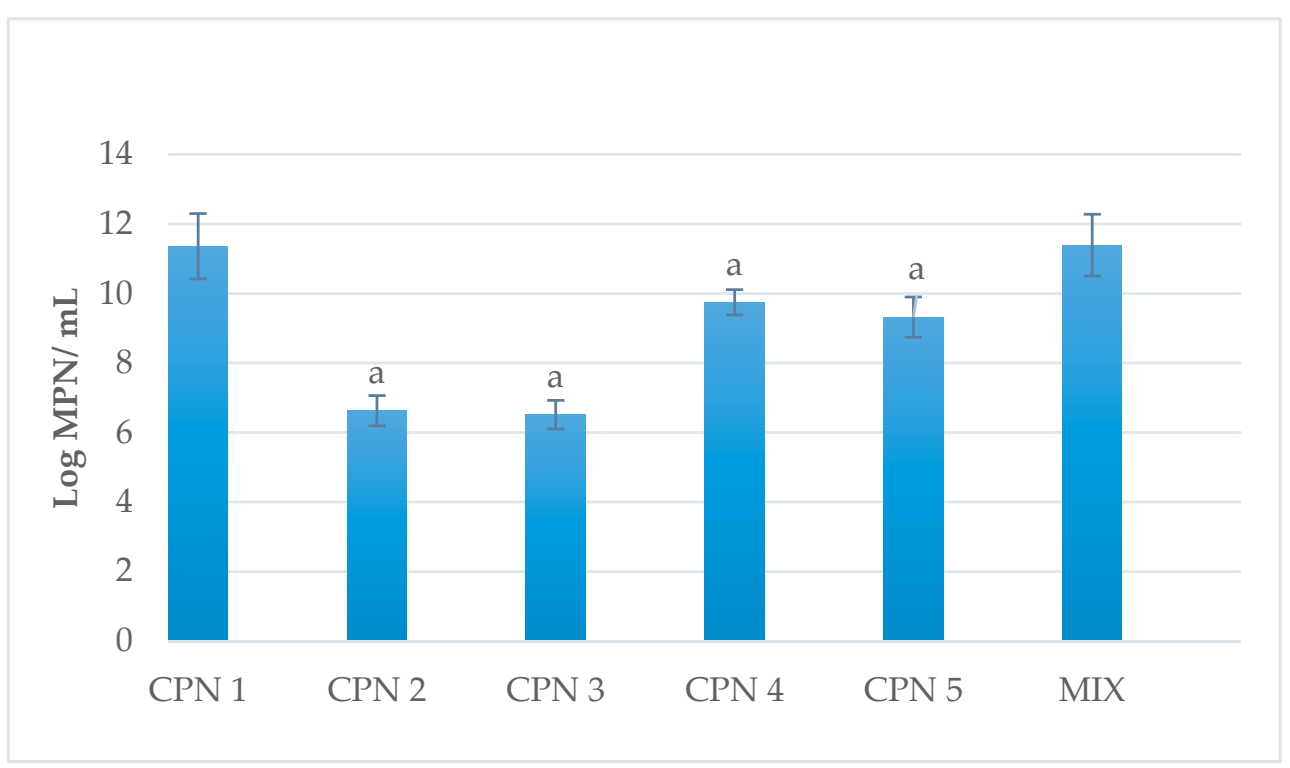

Figure 1. Abundance of hydrocarbons degraders, evaluated by the most-probable number (MPN) method, in the cultures inoculated with the bacterial strains isolated from a beach sediment, both as individual bacterial strains (CPN1, CPN2, CPN3, CPN4, CPN5) and as a mixture of the 5 bacterial strains (MIX) (mean values, standard deviations, $n=3$ ). a-significant differences compared with the MIX $(p<0.05)$.

\subsection{Growth Optimization of the Bacterial Consortium with 4 Different Carbon Sources}

To optimize the growth of the bacterial consortium (MIX), 4 different carbon sources were tested, and at the end of the 15 day experimental period, the abundance of hydrocarbon degrading-bacteria was analyzed. The cultures fed with petroleum and sodium acetate presented high densities of hydrocarbon degraders, respectively $10^{8}$ and $>10^{11} \mathrm{MPN} / \mathrm{mL}$ (Figure 2). The mixture of PAHs alone or in the presence of sodium acetate led to densities of hydrocarbon degraders below $10^{4} \mathrm{MPN} / \mathrm{mL}$. No significant differences were observed between these two latter groups, with the abundance of hydrocarbons degraders being significantly $(p<0.05)$ lower in these treatments than in the treatments with petroleum and sodium acetate. Both petroleum and acetate were selected as carbon sources for growth of the bacterial consortium for further studies. 


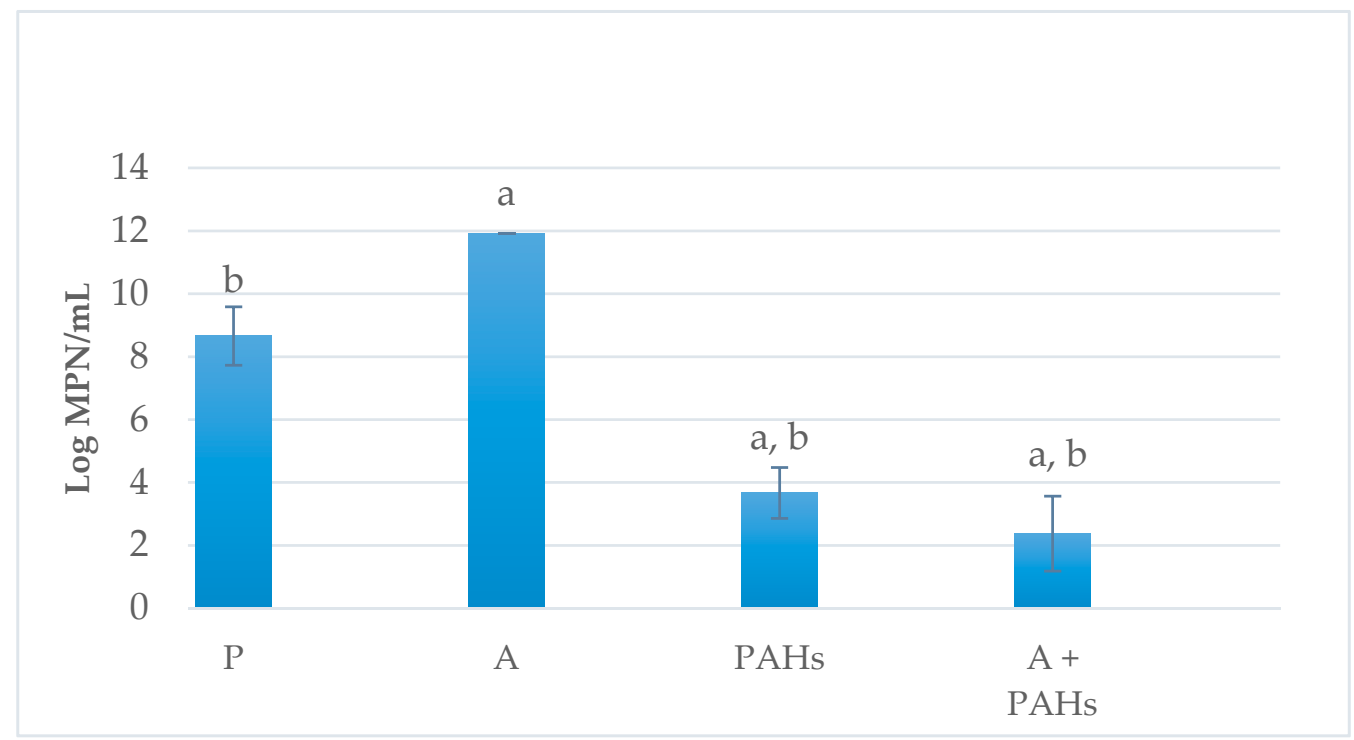

Figure 2. Abundance of hydrocarbons degraders, evaluated by the most-probable number (MPN) method, in the cultures inoculated with the mixture of 5 bacterial strains CPN1-CPN5 (mean value, standard deviation, $n=3$ ) grown with different carbon sources: petroleum (P), sodium acetate (A), a mixture of polycyclic aromatic hydrocarbons (PAHs) and a combination of sodium acetate with a mixture of PAHs (A + PAHs). a-significant differences comparing with the P treatment; $\mathrm{b}$-significant differences compared with the A treatment.

\subsection{Microcosm Bioremediation Experiment}

For the microcosm bioremediation experiment, two bacterial consortia pre-grown on the carbon sources previously selected (petroleum and sodium acetate) were prepared and used as inocula for the bioaugmentation treatments (BA/P and BA/A), that were compared with natural attenuation (NA) and biostimulation (BS).

For each treatment, photos were taken at the beginning and after 7 and 15 days of the experiment (Figure 3). At the beginning of the experiment (Figure 3a), a clear separation between the oil slick and the medium was observed for the 4 treatments. After 7 days of the experiment (Figure $3 b$ ), this separation was still observed for natural attenuation (NA) and biostimulation (BS) treatments, while for bioaugmentation (BA/P and BA/A) treatments a clear blending between the petroleum and the medium was observed. At the end of the experiment (Figure 3c), this separation was observed only for NA, while for BS a blending between the petroleum and the medium was observed, as for BA/P and BA/A.

Regarding the abundance of hydrocarbon degraders (Figure 4), the bioaugmentation (BA/P and BA/A) treatments presented, as expected, high values at the beginning of the experiment $\left(\mathrm{MPN} / \mathrm{mL}>10^{11}\right)$. However, the treatments natural attenuation (NA) and biostimulation (BS) also revealed the presence of hydrocarbon degraders at the beginning of the experiment, and their abundance increased after 15 days of the experiment. At the end of the experiment, no significant differences in terms of abundance of hydrocarbon degraders were observed between the treatments BS, BA/P and BA/A.

For each treatment, the percentage of TPHs removal was also evaluated (Figure 5). The results revealed that the biostimulation (BS) and bioaugmentation (BA/P and BA/A) treatments showed higher TPHs removal percentages than natural attenuation (NA). Although no significant differences were observed between the treatments BS, BA/P and $\mathrm{BA} / \mathrm{A}$, the latter, in which the consortium was pre-grown with sodium acetate, showed the highest removal percentage of TPHs $(66 \%)$. 

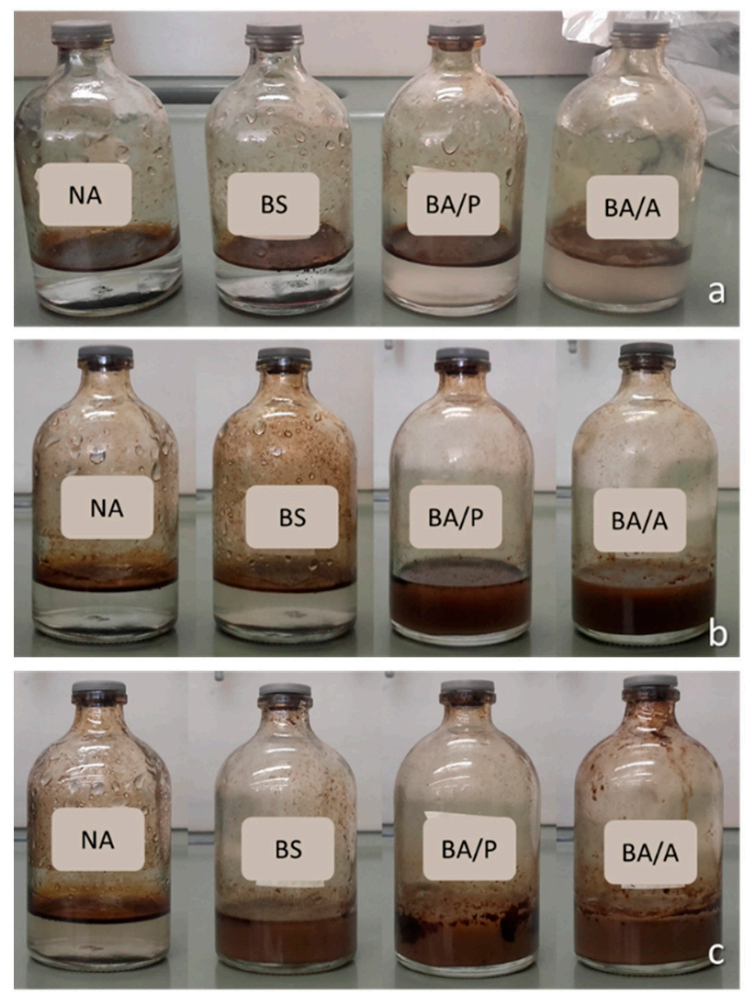

Figure 3. Visual aspect of the microcosm flasks at the beginning (a), after 7 days of the experiment (b) and at the end of the experiment (after 15 days) (c), for the different treatments: natural attenuation (NA), biostimulation (BS), bioaugmentation with inoculum pre-grown in petroleum (BA/P) and bioaugmentation with inoculum pre-grown in acetate (BA/A).

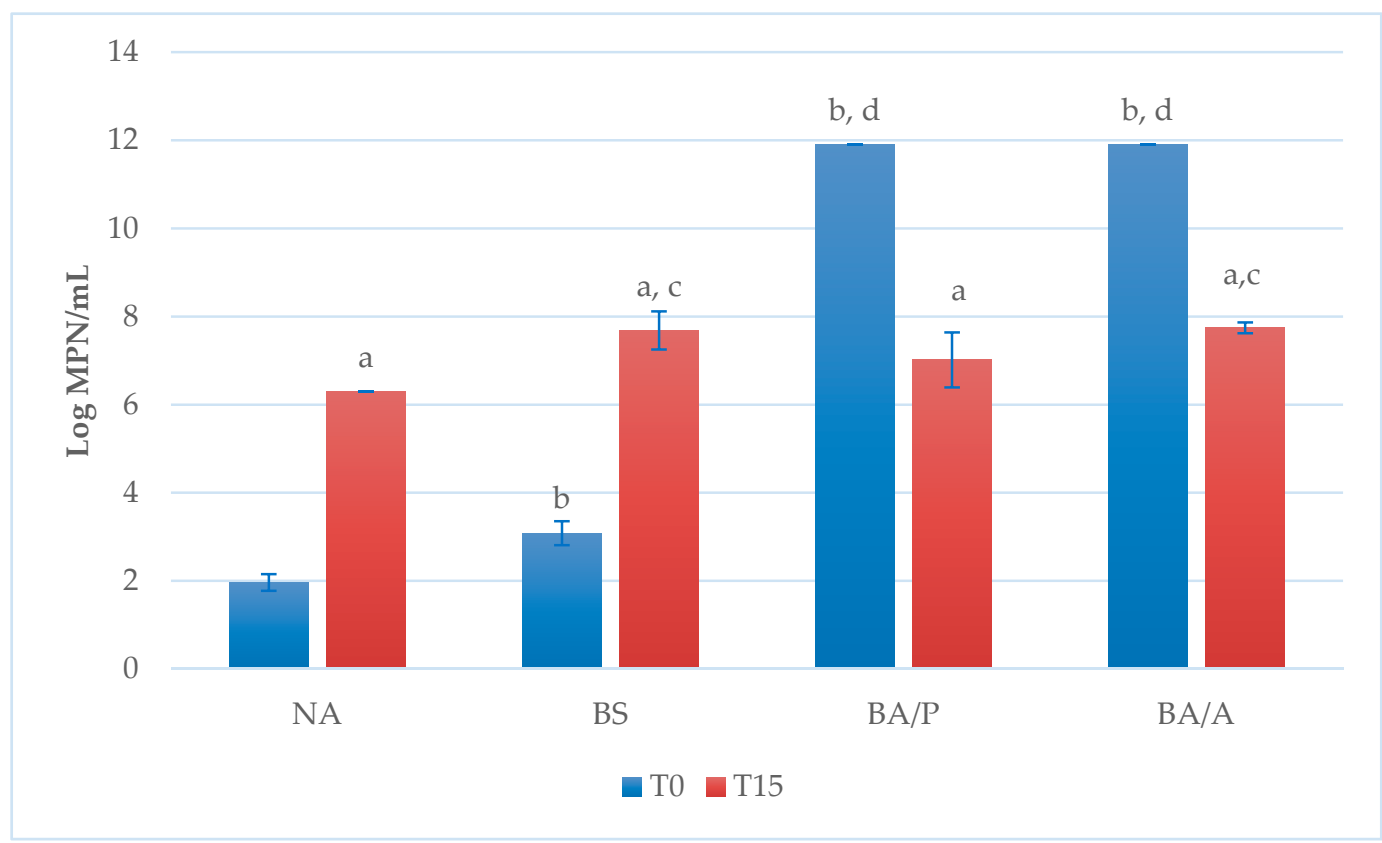

Figure 4. Abundance of hydrocarbon degrading bacteria, evaluated by the most-probable number (MPN) method, at the beginning (T0) and after 15 days (T15) of the microcosm experiment (mean values, standard deviations, $n=3$ ) for the different treatments: natural attenuation (NA), biostimulation (BS), bioaugmentation with inoculum pre-grown in petroleum (BA/P) and bioaugmentation with inoculum pre-grown in acetate (BA/A). a-significant differences between $\mathrm{T} 0$ and T15; $\mathrm{b}$ - significant differences comparing all treatments with NA in T0; $c$-significant differences comparing all treatments with NA in T15; $\mathrm{d}$-significant differences comparing BS with the BA treatments in T0. 


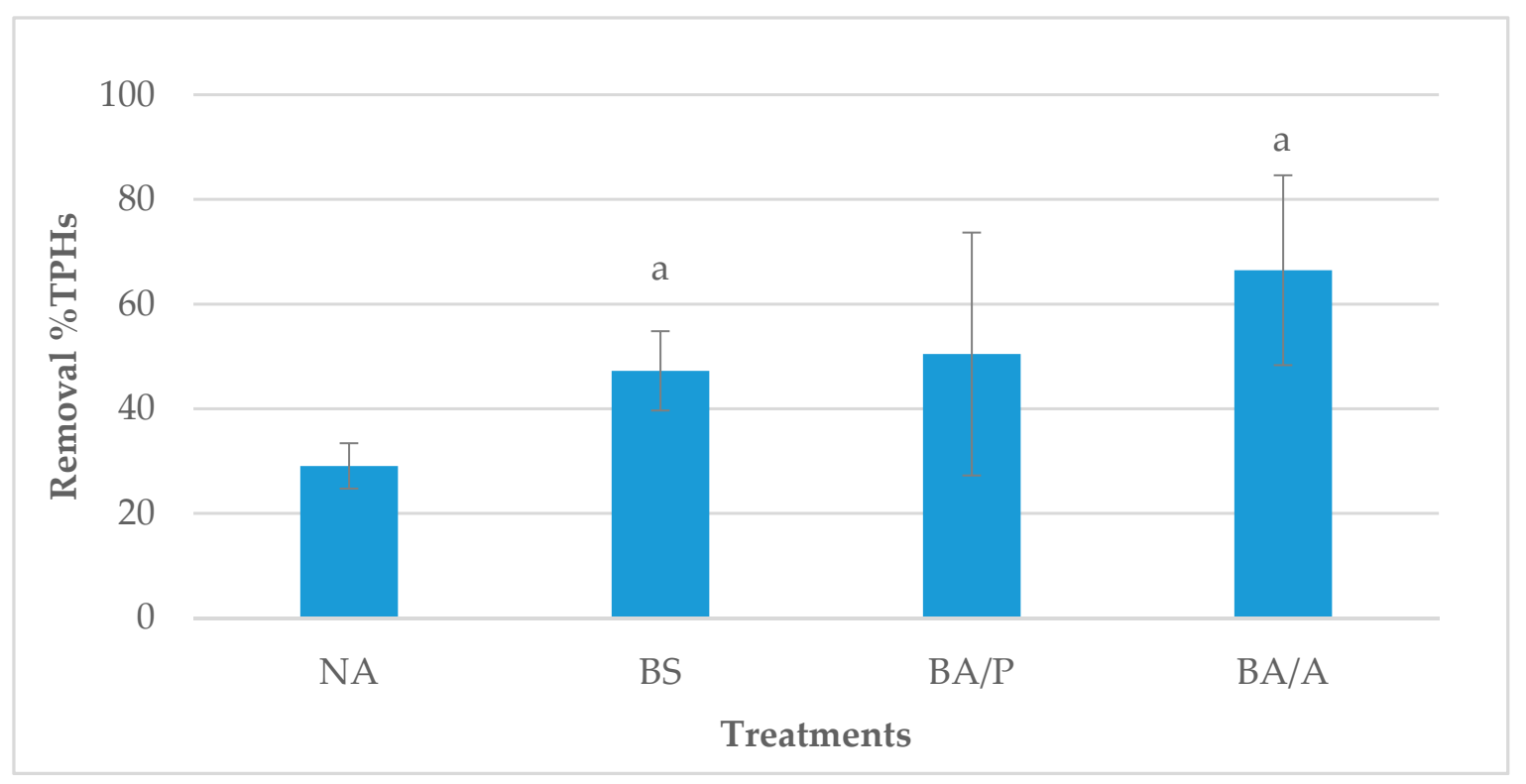

Figure 5. Removal percentage of total petroleum hydrocarbons (TPHs) (mean values, standard deviations, $n=3$ ) for the different treatments: natural attenuation (NA), biostimulation (BS), bioaugmentation with inoculum pre-grown in petroleum $(\mathrm{BA} / \mathrm{P})$ and bioaugmentation with inoculum pre-grown in acetate (BA/A). a — significant differences comparing each treatment with NA.

\subsection{Phylogenetic Identification of Hydrocarbon-Degrading Bacteria}

The bacterial strains (CPN1, CPN2, CPN3, CPN4 and CPN5) used to prepare the bacterial consortia used as inocula in the bioremediation experiment were phylogenetically identified through 16S rRNA gene sequencing as belonging to the phyla Proteobacteria and Actinobacteria, where they were identified as Pseudomonas sp., Rhodococcus erythropolis and Acinetobacter johnsonii (Table 1).

Phylogenetic identification of the bacterial strains isolated at the end of the microcosm bioremediation experiment revealed that the bacterial strains added to the bioaugmentation treatments (BA/P and BA/A) were successfully recovered (Tables 1 and 2) at the end of the experiment. In addition, it was possible to isolate several other bacterial strains (Table 2) from the different treatments. These were bacteria that were already present in the natural water and that were able to survive and grow on the petroleum used in the experiment.

Most of these bacterial strains were Proteobacteria from the genus Pseudomonas, but it was also possible to isolate some Actinobacteria.

For the isolates NA1, BS2, BS5 and BAP1, it was not possible to obtain an identification at a species or genus level in either of the 3 databases used. The search revealed that these isolated bacterial strains, belonging to the Rhodobacteraceae family, present correspondence to 3 genera (Albirhodobacter; Pseudohodobacter and Rhodobacter).

\section{Discussion}

In this work we were able to develop and optimize a bacterial consortium with high potential for degrading petroleum hydrocarbons when applied in a context of an autochthonous bioaugmentation technique with natural seawater.

The development of autochthonous bioremediation technologies for application in the recovery of oil spill incidents needs to be increased. A first step should pass through the screening of the native oil-degrading bacteria present at a target marine or coastal area, isolate them and optimize a bacterial consortium with the ability to degrade hydrocarbons, for a specific location. 
In the present work, 5 bacterial strains (CPN1-CPN5), isolated after exposure of a beach sediment to crude oil and cryopreserved in a georeferenced microbial bank, were used for the development of an optimized autochthonous consortium with high capability to degrade hydrocarbons, for bioremediation applications. These strains were identified as Pseudomonas sp. (strains CPN1 and CPN4), Rhodococcus erythropolis (strains CPN2 and CPN3) and Acinetobacter johnsonii (strain CPN5). All 5 bacterial strains showed potential to degrade petroleum hydrocarbons (evaluated by the MPN method), either as individual strains or as a bacterial consortium (mixture of the 5 strains). The capability of these bacterial strains to degrade hydrocarbons has been also reported in other studies. Pseudomonas are one of the major taxa associated to the biodegradation of hydrocarbons, due to their production of biosurfactants and to their superior metabolism of hydrocarbons [42-44]. Rhodoccocus erythropolis are well-known oil degrading bacteria, also described for their biosurfactant production ability and petroleum hydrocarbons degradation capacity $[45,46]$. The species Acinetobacter johnsonii belongs to a genus also known for its ability to degrade a large spectrum of hydrocarbons [47]. In addition, all the three genera include strains registered as patents for hydrocarbon degradation ability [27].

Since these bacterial strains were isolated from a sediment collected near an oil refinery, they could already have a predisposition to degrade petroleum hydrocarbons. As evidence, a recent study of Rocha, et al. [48], detected PAHs in concentrations harmful to the environment in water and sediment samples from two north-western Atlantic beaches close to the same oil refinery and to the Leixões harbor. This contamination was associated with anthropogenic activities linked to the refinery and the port.

As crude oil is a complex mixture of hydrocarbons and other compounds, and as different bacterial strains degrade distinct hydrocarbons, a consortium of hydrocarbondegrading bacteria can perform better in terms of petroleum hydrocarbon degradation than single bacterial strains $[7,49]$. For this reason, growth optimization of the bacterial consortium was considered for microcosms bioremediation experiments.

Several studies use crude oil or other hydrocarbon substrates to grow the consortia for bioaugmentation purposes [22,50]. In the present study, sodium acetate was selected as a possible carbon source for scale-up growth of the bacterial consortium because it is an easily metabolized carbon source used by most bacteria. This compound has been used before as a bacterial growth supporting substrate in experiments of biodegradation of other organic contaminants [51-54]. Two other substrates were also tested as potential carbon sources for scale-up growth of the bacterial consortium - crude oil and a mixture of PAHs. From the tested carbon sources, the mixture of PAHs, either alone or in combination with sodium acetate, revealed not to be effective in increasing the growth of hydrocarbon-degrading bacteria, with abundances of hydrocarbon degraders below $10^{4} \mathrm{MPN} / \mathrm{mL}$. This might be due to the fact that the concentration of the mixture of PAHs used, on the order of $10 \mathrm{~g} \cdot \mathrm{L}^{-1}$ each, was toxic to the bacterial strains, inhibiting their growth rate, or to the fact the bacterial consortium metabolized more slowly with the PAHs mixture, consequently resulting in a lower growth. In fact, aromatic hydrocarbons are usually more difficult to degrade [7]. In the study of Muangchinda et al. [55] a bacterial consortium, where Pseudomonas sp. was identified, previously enriched with a mixture of PAHs including naphthalene, anthracene, fluoranthene and pyrene, each in the concentration order of $10-30 \mathrm{mg} \cdot \mathrm{L}^{-1}$, revealed potential for PAHs degradation. Several other studies have highlighted the potential of species form the genera Pseudomonas, Rhodococcus erythropolis and Acinetobacter johnsonii to degrade PAHs compounds [55-57]. Nevertheless, in the present study, the mixture of PAHs was the carbon source that allowed a lower biomass growth and a lower abundance of hydrocarbons-degraders, when compared with acetate and petroleum. Despite the fact that PAHs are part of petroleum composition, petroleum also includes aliphatic compounds which are much more easily degraded, which could justify the fact that petroleum was a better carbon source for hydrocarbons-degraders growth. Given this result, these carbon sources (petroleum and sodium acetate) were selected for growing the bacterial consortium 
for the microcosm bioremediation experiment, to evaluate their hydrocarbon degradation potential when used as inocula for bioaugmentation.

The results of the microcosm bioremediation experiment showed that bioaugmentation with inocula pre-grown in acetate had the best performance. In fact, at the end of the 15 days experiment, the removal of TPHs in this treatment was ca. $66 \%$. Considering that these assays occurred in only 15 days and in the presence of the seawater natural community, the results of $66 \%$ TPHs removal are promising. Visual inspection of the flasks for the various treatments along the time of the experiment revealed a clear blending between petroleum and the medium for bioaugmentation treatment after 7 days, and for biostimulation treatment after 15 days, whereas in the natural attenuation a clear distinction of the oil layer and the media was still visible. This oil layer blending might have occurred due to the production of biosurfactants by the selected consortia, as the bacterial strains like Pseudomonas sp. and Rhodococcus erythropolis, present in our bacterial consortium, have been reported to produce biosurfactants $[45,58]$. The efficiency of bioaugmentation, and to a less degree biostimulation, in the increase of oil solubility and oil degradation was previously observed by Almeida et al. [24] and Pontes et al. [35] when studying the potential of a microbial community present in an unimpacted beach sediment to remediate petroleum hydrocarbons, respectively in microcosm and mesocosm experiments. It must be noted that, despite the high abundance of hydrocarbon-degraders observed at the beginning of our experiment for the bioaugmentation treatments, a clear decrease at the end of the experiment, most likely due to the decline of the carbon source associated with the removal of hydrocarbons. The same was observed by Pontes et al. [35] in a mesocosm experiment, with a different timeframe.

The application of autochthonous bioaugmentation is generally more advantageous than exogenous bioaugmentation, since exogenous bacterial strains may not be able to compete with the natural microbial community and tolerate abiotic factors of the site, resulting in less efficiency to degrade petroleum than autochthonous microorganisms [28]. The present study, together with the works of Almeida et al. [24] and Pontes et al. [35], evidence the success of using autochthonous bioaugmentation. Some other authors also studied the effect of bioaugmentation in petroleum degradation using microbial consortia enriched with crude oil [32,59-61]. Nikolopoulou et al. [32] studied the combined effect of biostimulation and autochthonous bioaugmentation with a consortium obtained from a seawater sample, for a period of 30 days and obtained a $77 \%$ removal of the saturated hydrocarbons fraction. The removal of the hydrocarbons was slightly higher than the one observed in the present study but our experiment occurred for a shorter period of time. Jurelevicius, et al. [62] observed 50\% degradation of TPHs after 32 days of a biostimulation treatment applied in water samples contaminated with crude oil. These results are comparable to the ones achieved in the present work in the biostimulation treatment, in which ca. 50\% of TPHs removal was observed, after just 15 days of incubation. Moreover, at the end of the experiment, Jurelevicius, et al. [62] found a predominance of microorganisms affiliated with the order Oceanospirillales, and with the genera Marinobacter, Mesoflavibacter and Pseudomonas, with the latter being also a representative genus of the current study. In a microcosm experiment designed to evaluate the bioremediation potential of microorganisms from intertidal sediments of a sandy beach affected by a major oil spill, Reis et al. [36] highlighted the potential of autochthonous microorganisms affiliated with the taxa Pseudomonas, Actinomycetales, and Betaproteobacteria for hydrocarbon degradation (up to $85 \%$ for TPHs), being the biodegradation stimulated by addition of nutrients.

At the end of the microcosms experiment, samples from the bioaugmentation treatments were cultured on agar plates and the recovered strains identified, to analyze if the bacterial strains of the initial consortia were still present at the end of the assay. Phylogenetic analysis showed that, after 15 days of microcosms experiments, all the bacterial strains present in the initial consortia were recovered from the bioaugmentation treatments $(\mathrm{BA} / \mathrm{P}$ and $\mathrm{BA} / \mathrm{P}$ ), indicating that these strains were able to survive, likely by using petroleum for their growth and contributing for the observed petroleum degradation. In fact, these were 
the treatments that displayed the highest petroleum removals. Additionally, in the bioaugmentation treatments, it was possible to isolate at the end of the microcosms experiment more bacterial strains than the ones present in the initial consortia. This results from the fact that the microcosm experiment was performed with non-sterilized natural seawater and, thus, some bacterial strains present in the seawater natural community were able to grow under the microcosm conditions and be recovered at the end of the experiment. The same was observed for the treatments that were not inoculated with the consortia. In the case of the natural attenuation (NA), it was clear that, despite the high number of strains that were isolated, the biodegrading potential of the microbial community was very limited, as shown by the results from hydrocarbon degradation. So, this work made clear that the hydrocarbon potential of the natural microbial communities needs to be stimulated by biostimulation and bioaugmentation strategies.

Overall, this study demonstrates that it is possible to produce an efficient petroleumdegrading bacterial consortium to be used as inoculum in autochthonous bioaugmentation without using petroleum or other hydrocarbons as carbon sources. This is of great importance in terms of biotechnology as it allows the production of high amounts of biomass without the use of hazardous compounds. Also, it was proven that the bacteria grown on this substrate kept their hydrocarbon degradation capacity and were able to survive and grow on petroleum, and therefore are efficient as a bioremediation tool.

Heading towards the development of an efficient bioremediation tool for application in real contaminated scenarios, a scale-up growth of the developed autochthonous bacterial consortium grown with sodium acetate might be considered in future remediation procedures for field bioaugmentation. In order to understand the geographical scale to which an autochthonous bacterial consortium can be applied, we are currently characterizing the microbial communities along the NW Iberian Peninsula coast. Samples collected under the Project Spilless (First line response to oil spills based on native microorganisms cooperation [Reference EASME/EMFF/2016/1.2.1.4/010]) are being organized in a georeferenced library of microorganisms that will allow understanding the geographic distribution of each bacterial strain. In addition, and indicating the ubiquity of oil-degrading microorganisms, the workflow developed in the present study can be adapted for application in other regions of the world.

For the implementation of nature-based technologies, such as bioremediation, there must be policies taken by companies that foster sustainable transition from more polluting technologies to less or non-polluting technologies. Plans like the recently launched Atlantic Action Plan 2.0 [63], that provide a framework for the growth of sustainable and competitive blue economy in the Atlantic area, whilst protecting marine and coastal environment, are essential to connect knowledge from science to technology and the economic sector. In addition, the study of Aldieri et al. [39] acknowledges that European companies in the field of water and energy, benefited from the application of environmental knowledge spillovers, increasing their productivity, contrarily to when corporate taxes were applied.

In this way, the application of autochthonous bioremediation techniques may allow tackling oil spill disasters with an eco-friendly, efficient, and economic approach, not only removing the petroleum, but also remediating the polluted environment and restoring its functions.

\section{Conclusions}

In this work, we developed a consortium of autochthonous hydrocarbon-degrading bacteria and optimized its growth using different carbon sources for application in bioaugmentation treatments.

Sodium acetate showed to be the best substrate for growth of the bacterial consortium, and the bioaugmentation treatment inoculated with the consortium pre-grown on this substrate resulted in the highest hydrocarbons degradation performance. Also, in this treatment, all the bacterial strains added were found at the end of the experiment. This study provides an insight into the capacity of autochthonous communities to degrade 
hydrocarbons and into the potential of using non-hazardous carbon sources to grow bacterial biomass for the development of bioremediation products to respond to oil spills.

The assembled consortium could be applied in the future, through bioremediation technologies, at the geographic region from which the bacterial strains were obtained, in case of an oil spill scenario.

More studies should now test the efficiency of the developed consortium to degrade different hydrocarbons, namely aromatic ones, as well as screening for biosurfactant production and testing the developed consortium in large scale experiments mimicking real environmental conditions.

Supplementary Materials: The following are available online at https:/ / www.mdpi.com/2073-444 1/13/1/66/s1, Figure S1: Growth of the mixture of isolates CPN1-CPN5, with sodium acetate added to the flasks daily (A) and twice a week (B) (mean values, standard deviation, $n=2)$; Figure S2: Scheme of microcosm experiment with the tested treatments: Natural attenuation (NA), Biostimulation (BS), Bioaugmentation with inoculum pre-grown in petroleum (BA/P) and bioaugmentation with inoculum pre-grown in acetate (BA/A). SW: seawater, P: petroleum, A: acetate.

Author Contributions: Conceptualization, R.P., F.S., C.M.R.A., M.F.C. and A.P.M.; methodology, R.P., F.S.; validation, R.P., F.S., C.M.R.A., M.F.C. and A.P.M.; formal analysis, R.P., F.S.; investigation, R.P., C.M.R.A., M.F.C. and A.P.M.; resources, C.M.R.A., M.F.C. and A.P.M.; writing-original draft preparation, R.P.; writing-review and editing, C.M.R.A., M.F.C. and A.P.M.; supervision, C.M.R.A., M.F.C. and A.P.M.; project administration, A.P.M.; funding acquisition, C.M.R.A., M.F.C. and A.P.M. All authors have read and agreed to the published version of the manuscript.

Funding: This research was partially supported by the project BIOREM-Bioremediation of hydrocarbon pollutants by autochthonous microorganisms in aquatic environment, PTDC/BTA-GES/32186/ 2017 and POCI-01-0145-FEDER-032186, supported by Fundo Europeu de Desenvolvimento Regional through COMPETE2020-Programa Operacional de Competitividade e Internacionalização (POCI) and FCT/MCTES; by national funds through FCT-Foundation for Science and Technology within the scope of UIDB/04423/2020 and UIDP/04423/2020.

Institutional Review Board Statement: Not applicable.

Informed Consent Statement: Not applicable.

Data Availability Statement: The data presented in this study are available in the current article and the supplementary material associated with it, freely available at Water.

Conflicts of Interest: The authors declare no conflict of interest. The funders had no role in the design of the study; in the collection, analyses, or interpretation of data; in the writing of the manuscript, or in the decision to publish the results.

\section{References}

1. Jin, M.; Shi, W.; Yuen, K.F.; Xiao, Y.; Li, K.X. Oil tanker risks on the marine environment: An empirical study and policy implications. Mar. Policy 2019, 108, 103655. [CrossRef]

2. Kaluza, P.; Kolzsch, A.; Gastner, M.T.; Blasius, B. The complex network of global cargo ship movements. J. R. Soc. Interface 2010, 7, 1093-1103. [CrossRef] [PubMed]

3. Ivshina, I.B.; Kuyukina, M.S.; Krivoruchko, A.V.; Elkin, A.A.; Makarov, S.O.; Cunningham, C.J.; Peshkur, T.A.; Atlas, R.M.; Philp, J.C. Oil spill problems and sustainable response strategies through new technologies. Environ. Sci. Process. Impacts 2015, 17, 1201-1219. [CrossRef] [PubMed]

4. Xue, J.; Yu, Y.; Bai, Y.; Wang, L.; Wu, Y. Marine Oil-Degrading Microorganisms and Biodegradation Process of Petroleum Hydrocarbon in Marine Environments: A Review. Curr. Microbiol. 2015, 71, 220-228. [CrossRef]

5. Das, N.; Chandran, P. Microbial degradation of petroleum hydrocarbon contaminants: An overview. Biotechnol. Res. Int. 2011, 2011, 941810. [CrossRef]

6. Leahy, J.G.; Colwell, R.R. Microbial degradation of hydrocarbons in the environment. Microbiol. Rev. 1990, 54, 305-315. [CrossRef]

7. Hassanshahian, M.; Cappello, S. Crude oil biodegradation in the marine environments. In Biodegradation-Engineering and Technology; Chamy, R., Rosenkranz, F., Eds.; InTech: London, UK, 2013.

8. Gong, Y.; Zhao, X.; Cai, Z.; O'Reilly, S.E.; Hao, X.; Zhao, D. A review of oil, dispersed oil and sediment interactions in the aquatic environment: Influence on the fate, transport and remediation of oil spills. Mar. Poll. Pollut. 2014, 79, 16-33. [CrossRef]

9. Mishra, A.K.; Kumar, G.S. Weathering of Oil Spill: Modeling and Analysis. Aquat. Procedia 2015, 4, 435-442. [CrossRef] 
10. Acosta-González, A.; Martirani-von Abercron, S.-M.; Rosselló-Móra, R.; Wittich, R.-M.; Marqués, S. The effect of oil spills on the bacterial diversity and catabolic function in coastal sediments: A case study on the Prestige oil spill. Environ. Sci. Pollut. Res. 2015, 22, 15200-15214. [CrossRef]

11. Shetaia, Y.M.; El Khalik, W.A.; Mohamed, T.M.; Farahat, L.A.; ElMekawy, A. Potential biodegradation of crude petroleum oil by newly isolated halotolerant microbial strains from polluted Red Sea area. Mar. Pollut. Bull. 2016, 111, 435-442. [CrossRef]

12. Bovio, E.; Gnavi, G.; Prigione, V.; Spina, F.; Denaro, R.; Yakimov, M.; Calogero, R.; Crisafi, F.; Varese, G.C. The culturable mycobiota of a Mediterranean marine site after an oil spill: Isolation, identification and potential application in bioremediation. Sci. Total Environ. 2017, 576, 310-318. [CrossRef] [PubMed]

13. Abbasian, F.; Lockington, R.; Mallavarapu, M.; Naidu, R. A Comprehensive Review of Aliphatic Hydrocarbon Biodegradation by Bacteria. Appl. Biochem. Biotechnol. 2015, 176, 670-699. [CrossRef]

14. Guo-liang, Z.; Yue-ting, W.; Xin-ping, Q.; Qin, M. Biodegradation of crude oil by Pseudomonas aeruginosa in the presence of rhamnolipids. J. Zhejiang Univ. Sci. B 2005, 6, 725-730.

15. Martinkova, L.; Uhnakova, B.; Patek, M.; Nesvera, J.; Kren, V. Biodegradation potential of the genus Rhodococcus. Environ. Int. 2009, 35, 162-177. [CrossRef] [PubMed]

16. De Carvalho, C.; da Fonseca, M.M.R. The remarkable Rhodococcus erythropolis. Appl. Microbiol. Biotechnol. 2005, 67, 715-726. [CrossRef] [PubMed]

17. Cappello, S.; Santisi, S.; Calogero, R.; Hassanshahian, M.; Yakimov, M.M. Characterisation of Oil-Degrading Bacteria Isolated from Bilge Water. Water Air Soil Pollut. 2012, 223, 3219-3226. [CrossRef]

18. Yakimov, M.M.; Timmis, K.N.; Golyshin, P.N. Obligate oil-degrading marine bacteria. Curr. Opin. Biotechnol. 2007, 18, 257-266. [CrossRef]

19. Syakti, A.D.; Lestari, P.; Simanora, S.; Sari, L.K.; Lestari, F.; Idris, F.; Agustiadi, T.; Akhlus, S.; Hidayati, N.V. Culturable hydrocarbonoclastic marine bacterial isolates from Indonesian seawater in the Lombok Strait and Indian Ocean. Heliyon 2019, 5, e01594. [CrossRef]

20. Al-Majed, A.A.; Adebayo, A.R.; Hossain, M.E. A sustainable approach to controlling oil spills. J. Environ. Manag. 2012, 113, 213-227. [CrossRef]

21. Crisafi, F.; Genovese, M.; Smedile, F.; Russo, D.; Catalfamo, M.; Yakimov, M.; Giuliano, L.; Denaro, R. Bioremediation technologies for polluted seawater sampled after an oil-spill in Taranto Gulf (Italy): A comparison of biostimulation, bioaugmentation and use of a washing agent in microcosm studies. Mar. Pollut. Bull. 2016, 106, 119-126. [CrossRef]

22. Li, X.; Zhao, L.; Adam, M. Biodegradation of marine crude oil pollution using a salt-tolerant bacterial consortium isolated from Bohai Bay, China. Mar. Pollut. Bull. 2016, 105, 43-50. [CrossRef] [PubMed]

23. Priya, A.; Manab Sarma, P.; Lal, B. Isolation and characterization ofCandida vishwanathiistrain TERI MS1 for degradation of petroleum hydrocarbons in marine environment. Desalination Water Treat. 2016, 57, 22099-22106. [CrossRef]

24. Almeida, C.M.; Reis, I.; Couto, M.N.; Bordalo, A.A.; Mucha, A.P. Potential of the microbial community present in an unimpacted beach sediment to remediate petroleum hydrocarbons. Environ. Sci. Pollut. Res. Int. 2013, 20, 3176-3184. [CrossRef] [PubMed]

25. Prince, R.; Lessard, R.; Clark, J. Bioremediation of marine oil spills. Oil Gas Sci. Technol. 2003, 58, 463-468. [CrossRef]

26. Nikolopoulou, M.; Kalogerakis, N. Biostimulation strategies for fresh and chronically polluted marine environments with petroleum hydrocarbons. J. Chem. Technol. Biotechnol. Int. Res. Process Environ. Clean Technol. 2009, 84, 802-807. [CrossRef]

27. Villela, H.D.M.; Peixoto, R.S.; Soriano, A.U.; Carmo, F.L. Microbial bioremediation of oil contaminated seawater: A survey of patent deposits and the characterization of the top genera applied. Sci. Total Environ. 2019, 666, 743-758. [CrossRef]

28. Hosokawa, R.; Nagai, M.; Morikawa, M.; Okuyama, H. Autochthonous bioaugmentation and its possible application to oil spills. World J. Microbiol. Biotechnol. 2009, 25, 1519-1528. [CrossRef]

29. Fodelianakis, S.; Antoniou, E.; Mapelli, F.; Magagnini, M.; Nikolopoulou, M.; Marasco, R.; Barbato, M.; Tsiola, A.; Tsikopoulou, I.; Giaccaglia, L.; et al. Allochthonous bioaugmentation in ex situ treatment of crude oil-polluted sediments in the presence of an effective degrading indigenous microbiome. J. Hazard. Mater 2015, 287, 78-86. [CrossRef]

30. Tao, K.; Liu, X.; Chen, X.; Hu, X.; Cao, L.; Yuan, X. Biodegradation of crude oil by a defined co-culture of indigenous bacterial consortium and exogenous Bacillus subtilis. Bioresour. Technol. 2017, 224, 327-332. [CrossRef]

31. Mapelli, F.; Scoma, A.; Michoud, G.; Aulenta, F.; Boon, N.; Borin, S.; Kalogerakis, N.; Daffonchio, D. Biotechnologies for Marine Oil Spill Cleanup: Indissoluble Ties with Microorganisms. Trends Biotechnol. 2017. [CrossRef]

32. Nikolopoulou, M.; Eickenbusch, P.; Pasadakis, N.; Venieri, D.; Kalogerakis, N. Microcosm evaluation of autochthonous bioaugmentation to combat marine oil spills. New Biotechnol. 2013, 30, 734-742. [CrossRef] [PubMed]

33. Bacosa, H.P.; Suto, K.; Inoue, C. Bacterial community dynamics during the preferential degradation of aromatic hydrocarbons by a microbial consortium. Int. Biodeterior. Biodegrad. 2012, 74, 109-115. [CrossRef]

34. Vila, J.; Maria Nieto, J.; Mertens, J.; Springael, D.; Grifoll, M. Microbial community structure of a heavy fuel oil-degrading marine consortium: Linking microbial dynamics with polycyclic aromatic hydrocarbon utilization. FEMS Microbiol. Ecol. 2010, 73, 349-362. [CrossRef] [PubMed]

35. Pontes, J.; Mucha, A.P.; Santos, H.; Reis, I.; Bordalo, A.; Basto, M.C.; Bernabeu, A.; Almeida, C.M. Potential of bioremediation for buried oil removal in beaches after an oil spill. Mar. Pollut. Bull. 2013, 76, 258-265. [CrossRef] 
36. Reis, I.; Almeida, C.M.; Magalhaes, C.M.; Cochofel, J.; Guedes, P.; Basto, M.C.; Bordalo, A.A.; Mucha, A.P. Bioremediation potential of microorganisms from a sandy beach affected by a major oil spill. Environ. Sci. Pollut. Res. Int. 2014, 21, $3634-3645$. [CrossRef]

37. Gouveia, V.; Almeida, C.M.R.; Almeida, T.; Teixeira, C.; Mucha, A.P. Indigenous microbial communities along the NW Portuguese Coast: Potential for hydrocarbons degradation and relation with sediment contamination. Mar. Pollut. Bull. 2018, 131, 620-632. [CrossRef]

38. Elisabeth Helmke, B.D.; Birte Gerdes, B.D.J.; Juergens, B.D.K.; Reuter, L.D. Bioremediation Method for Accelerated Biological Decomposition of Petroleum Hydrocarbons in Sea-Iced Covered Polar Regions, and Bacteria and Enzyme Mixtures as Agents for Carrying Out Said Method. U.S. Patent 8,444,962 B2, 21 May 2013.

39. Aldieri, L.; Makkonen, T.; Vinci, C.P. Environmental knowledge spillovers and productivity: A patent analysis for large international firms in the energy, water and land resources fields. Resour. Policy 2020, 69, 101877. [CrossRef]

40. Gouveia, V. Bioremediation of Oil Along the Nw Portuguese Coast-the Role of Autochthonous Microorganisms. Master's Thesis, University of Porto, Porto, Portugal, 2015. Available online: https://repositorio-aberto.up.pt/handle/10216/87315 (accessed on 28 June 2019).

41. Wrenn, B.A.; Venosa, A.D. Selective enumeration of aromatic and aliphatic hydrocarbon degrading bacteria by a most-probablenumber procedure. Can. J. Microbiol. 1996, 42, 252-258. [CrossRef]

42. Banat, I.M.; Franzetti, A.; Gandolfi, I.; Bestetti, G.; Martinotti, M.G.; Fracchia, L.; Smyth, T.J.; Marchant, R. Microbial biosurfactants production, applications and future potential. Appl. Microbiol. Biotechnol. 2010, 87, 427-444. [CrossRef]

43. Ron, E.Z.; Rosenberg, E. Biosurfactants and oil bioremediation. Curr. Opin. Biotechnol. 2002, 13, 249-252. [CrossRef]

44. Domingues, P.M.; Oliveira, V.; Serafim, L.S.; Gomes, N.; Cunha, Â. Biosurfactant Production in Sub-Oxic Conditions Detected in Hydrocarbon-Degrading Isolates from Marine and Estuarine Sediments. Int. J. Environ. Res. Public Health 2020, $17,1746$. [CrossRef] [PubMed]

45. Peng, F.; Liu, Z.; Wang, L.; Shao, Z. An oil-degrading bacterium: Rhodococcus erythropolis strain 3C-9 and its biosurfactants. J. Appl. Microbiol. 2007, 102, 1603-1611. [CrossRef] [PubMed]

46. Luong, T.M.; Ponamoreva, O.N.; Nechaeva, I.A.; Petrikov, K.V.; Delegan, Y.A.; Surin, A.K.; Linklater, D.; Filonov, A.E. Characterization of biosurfactants produced by the oil-degrading bacterium Rhodococcus erythropolis S67 at low temperature. World J. Microbiol. Biotechnol. 2018, 34, 20. [CrossRef] [PubMed]

47. Lee, M.; Woo, S.G.; Ten, L.N. Characterization of novel diesel-degrading strains Acinetobacter haemolyticus MJ01 and Acinetobacter johnsonii MJ4 isolated from oil-contaminated soil. World J. Microbiol. Biotechnol. 2012, 28, 2057-2067. [CrossRef]

48. Rocha, M.J.; Dores-Sousa, J.L.; Cruzeiro, C.; Rocha, E. PAHs in water and surface sediments from Douro River estuary and Porto Atlantic coast (Portugal)-impacts on human health. Environ. Monit. Assess 2017, 189, 425. [CrossRef]

49. Dell'Anno, A.; Beolchini, F.; Rocchetti, L.; Luna, G.M.; Danovaro, R. High bacterial biodiversity increases degradation performance of hydrocarbons during bioremediation of contaminated harbor marine sediments. Environ. Pollut. 2012, 167, 85-92. [CrossRef]

50. Mulani, N.; Fulke, A.B.; D’Souza, E.; Ram, A.; Maloo, A.; Sayed, F.; Gajbhiye, S.N. Biodegradation of Crude Oil Using Marine Bacillus species from Vadinar Coast, Gujarat, India. Curr. Sci. 2017, 112, 569. [CrossRef]

51. Alexandrino, D.A.; Mucha, A.P.; Almeida, C.M.R.; Gao, W.; Jia, Z.; Carvalho, M.F. Biodegradation of the veterinary antibiotics enrofloxacin and ceftiofur and associated microbial community dynamics. Sci. Total Environ. 2017, 581, 359-368. [CrossRef]

52. Alexandrino, D.A.M.; Ribeiro, I.; Pinto, L.M.; Cambra, R.; Oliveira, R.S.; Pereira, F.; Carvalho, M.F. Biodegradation of mono-, diand trifluoroacetate by microbial cultures with different origins. New Biotechnol. 2018, 43, 23-29. [CrossRef]

53. Duarte, P.; Almeida, C.M.R.; Fernandes, J.P.; Morais, D.; Lino, M.; Gomes, C.R.; Carvalho, M.F.; Mucha, A.P. Bioremediation of bezafibrate and paroxetine by microorganisms from estuarine sediment and activated sludge of an associated wastewater treatment plant. Sci. Total Environ. 2019, 655, 796-806. [CrossRef]

54. Santos, F.; Mucha, A.P.; Alexandrino, D.A.M.; Almeida, C.M.R.; Carvalho, M.F. Biodegradation of enrofloxacin by microbial consortia obtained from rhizosediments of two estuarine plants. J. Environ. Manag. 2019, 231, 1145-1153. [CrossRef] [PubMed]

55. Muangchinda, C.; Rungsihiranrut, A.; Prombutara, P.; Soonglerdsongpha, S.; Pinyakong, O. 16S metagenomic analysis reveals adaptability of a mixed-PAH-degrading consortium isolated from crude oil-contaminated seawater to changing environmental conditions. J. Hazard. Mater. 2018, 357, 119-127. [CrossRef] [PubMed]

56. Lang, F.S.; Destain, J.; Delvigne, F.; Druart, P.; Ongena, M.; Thonart, P. Biodegradation of polycyclic aromatic hydrocarbons in mangrove sediments under different strategies: Natural attenuation, biostimulation, and bioaugmentation with Rhodococcus erythropolis T902. 1. Water Air Soil Pollut. 2016, 227, 297. [CrossRef]

57. Jiang, Y.; Zhang, Z.; Zhang, X. Co-biodegradation of pyrene and other PAHs by the bacterium Acinetobacter johnsonii. Ecotoxicol. Environ. Saf. 2018, 163, 465-470. [CrossRef]

58. Makkar, R.S.; Cameotra, S.S.; Banat, I.M. Advances in utilization of renewable substrates for biosurfactant production. $A M B$ Express 2011, 1, 5. [CrossRef]

59. Santisi, S.; Cappello, S.; Catalfamo, M.; Mancini, G.; Hassanshahian, M.; Genovese, L.; Giuliano, L.; Yakimov, M.M. Biodegradation of crude oil by individual bacterial strains and a mixed bacterial consortium. Braz. J. Microbiol. 2015, 46, 377-387. [CrossRef]

60. Malik, Z.; Ahmed, S. Degradation of petroleum hydrocarbons by oil field isolated bacterial consortium. Afr. J. Biotechnol. 2012, 11, 650-658. [CrossRef] 
61. Bao, M.-T.; Wang, L.-N.; Sun, P.-Y.; Cao, L.-X.; Zou, J.; Li, Y.-M. Biodegradation of crude oil using an efficient microbial consortium in a simulated marine environment. Mar. Pollut. Bull. 2012, 64, 1177-1185. [CrossRef]

62. Jurelevicius, D.; Alvarez, V.M.; Marques, J.M.; Lima, L.; Dias, F.D.; Seldin, L. Bacterial Community Response to Petroleum Hydrocarbon Amendments in Freshwater, Marine, and Hypersaline Water-Containing Microcosms. Appl. Environ. Microbiol. 2013, 79, 5927-5935. [CrossRef]

63. European Commission (COM/2020/329 Final). Communication from the Commission to the European Parliament, the Council, the European Economic and Social Committee and the Committee of the Regions, An updated Action Plan for a Sustainable, Resilient and Competitive Blue Economy in the European Union Atlantic Area. 2020. Available online: https:/ / eur-lex.europa. eu/legal-content/EN/TXT/?uri=COM\%3A2020\%3A329\%3AFIN (accessed on 28 September 2020). 